\title{
実践研究
}

\section{書字や描画に困難をもつ一脳性麻盘児の認知特性の把握と それに応じた指導の効果からみた地域支援のあり方}

\author{
保 坂 俊 行
}

\begin{abstract}
本研究は、書字や描画に困難をきたしていた、脳質周囲白質軟化症による一脳性麻痺児を 対象にした事例研究である。入学した小学校での指導にあたり、特別支援学校による地域支 援と連携をとり、困難の原因について心理検査等によるアセスメントが行われた。その結果、 児がもつ困難は、身体の麻痺によるものより、視知覚の困難からくる認知特性による影響が 強いことが推測された。そこで、推測された認知特性に応じた指導を行った結果、 1 年後に 実施したフロスティッグ視知覚発達検査では、「知覚と運動の協応」「図形と素地」「形の恒 常性」の評価点の向上がみられた。また、書字についても、マスにバランスよく書けるよう になるといった書字能力の向上がみら机、人物画についても、顔や全身の各パーツの把握や バランスについて同年齢の子どもと同じ水準で描けるようになった。これらの結果から、本 事例が有していた書字や描画困難の原因、指導の効果、地域支援のあり方が検討された。
\end{abstract}

キー・ワード：脳性麻痺 認知特性 特別支援学校 地域支援

\section{I . 問題と目的}

本研究の対象となった事例は、脳質周囲白質軟化症 (periventricular leukomalacia, 以下 PVLとする)を原因 疾患とする痤直型脳性麻痺（左片麻痺）児である。対 象児は幼児期より書字や描画に困難をきたし、保護者 と担任からの「書字等の困難は身体の麻痺によるもの なのか、ほかに原因があるのか、もし麻痺以外の理由 があるのなら、身体機能のリハビリ以外に改善のため の指導・支援の方法があるのか知りたい」という主訴 により、筆者が所属する特別支援学校の地域支援によ る教育相談が開始された。

脳性麻痺児の学習について、安藤・野戸谷・任・小 山・丹野・原・松本・森・渡邊（2006）は、調查の対 象となった脳性麻疩群の WISC-III の群指数の特性か ら、認知特性を考慮した支援が必要であるとの示唆を 得ている。脳性麻痺児の認知特性について、国内では 曻地が実験による分析を行っており、脳性麻痺児は健 常児と比較して視覚走査的認知には障害は認められな いが、全体一部分と図一地などの関係を分解、分析、 回転、統合し、動作として操作的に働きかける手操作

山梨県立富士見支援学校旭分校

(前所属：山梨県立甲府支援学校)
的譛知に著しい障害が認められることを明らかにした (曻地, 1971, 1978, 1983)。そして、これらを総合して、 脳性麻痺児の視覚一運動障害の基本的な問題は対象の 認知・并別 (視知覚) の障害ではなく、認知・弁別し たものの構成（再生・表現）の障害であると述べてい る(曻地, 1984)。しかし、構成障害に関して仲山 (1984) は、視知覚のより高度な機能である図形の諸要素の空 間関係を抽象する分節機能の低水準に起因する可能性 を示唆した。このような脳性麻痺児がもつ諗知特性が、 小学校に入学してからは、書字、描画の困難や図形の 理解等の面の学習に影響を及ぼすことが考えられる (川間, 2008)。

脳性麻痺児がもつ視知覚障害等の発生機序として、 (1) 斜視、弱視、乱視などの視力の異常、(2) 麻痺によ る運動障害を基盤とする経験不足、(3) 眼球運動障害の 3 つの仮説が提唱されている。そして、近年の画像診 断の進歩により、脳の病巣からの原因が明らかになり つつある（小枝, 1993）。

そのひとつとして、低出生体重児に発症しやすい PVL が画像診断により認識されるようになってきた (茨・荻田, 2000)。そして、新生児医療の急速な進歩 により、近年、超低出生体重児の 8 割が生存し、その 8 割が後遺症がないという結果が報告されている一 
方、早産児における PVLによる脳性麻痺や注意欠陥 多動性障害の発症が問題となっている（高橋, 2002）。

フロスティッグ視知覚発達検査（以下、DTVP とす る）等の発達検査と脳の画像診断を組み合わせた、 PVL を有する児の視知覚障害等に関する研究により、 脳の責任病巣と視知覚障害等の特徵との関連が推測さ れた（荏原・太田・伊藤・北原, 2005; 小枝・渡辺・木 村・西・竹下, 1990)。側脳室側腹三角周辺の後部脳室 背側周囲にある連合繊維は、視知覚認知のような高次 脳機能や随意的眼球運動に関係していると考えられ、 これらの繊維の障害の組み合わせが、PVLを有する児 において視知覚認知の複雑な病態を生じさせると考元 られている（荏原・太田・染屋・田辺, 1999）。

このような脳性麻痺児の認知特性からくる困難に対 して、本人の得意な継次処理能力を生かした学習（山 中・藤田・名川, 1996)、なぞり書きや、手添えでの誘 導による書字指導（松本・北村, 2000)、コントロール された前庭系刺激の入力を中心とする感覚統合訓練の 実施（酒井・山田, 2001）、体性感覚と視覚情報を組み 合わせた感覚運動経験を重視した訓練の実施（伊藤・ 冨田, 2004）等による改善が報告されている。また、 山口（2008）は、DTVPの「視覚と運動の協応」に関 するトレーニングを、木村・渡辺・西・小枝（1992） は、フロスティッグ視知覚能力促進法を用いた訓練を 実施し、一定の効果が確かめられている。

一方、石井・飯塚・築田・川端・長嶋（2007）は、 発達障害児が図形を模写する過程での眼球運動を記録 した結果、視線移動のみでの模写が行えないなどの眼 球運動の問題を明らかにした。奥村・若宮・宇野・藤 庭・阪上・竹内・玉井（2008）は、視写困難を呈して いた頭頂葉・後頭葉萎縮を認める硬膜下血腫後遺症児 に対し、コンピューターソフトを用いた眼球運動卜 レーニングが有効であったと報告している。また、内 藤（2002）は学習困難、不注意の原因として、視覚機 能の問題からくる視覚的認知や行動面への影響を指摘 し、その改善のためにビジョン・トレーニングが有効 であるとし、学校でできるトレーニングの方法を紹介 している。

このように、脳性麻痺児が有する認知特性に起因す る学習上の困難を改善するための有効な指導方法が蓄 積されているにもかかわらず、安藤・渡邊・松本・ 任・小山・丹野（2007）は、調査の対象となった肢体 不自由特別支援学校の多くにおいて地域支援が行われ ているものの、肢体不自由览への支援の件数は少な く、支援内容も、身体のことや補装具などの目に見え
る部分への支援が多く、認知の偏りや心理面の問題 といった部分への支援は少ないという問題を指摘して いる。

そこで、本研究では、肢体不自由特別支援学校から 地域の小学校に在籍するPVLを原因疾患とする肢体 不自由児に対して、認知特性を考慮した支援を行った 経過を検討することにより、肢体不自由児に対する地 域支援のあり方について考察することを目的とする。

\section{II．対象児}

1. プロフィール

小学校の肢体不自由特別支援学級に在籍する女监。 人学してすぐに、担任より筆者の所属する特別支援学 校に依頼があり、教育相談がはじまった。相談開始時 の年齢は、6 歳 7 か月であった。診断名は、PVLによ る脳性麻痺（左㾏性麻痺）である。身体障害者手帳に よる障害の程度は、左上肢 3 級、左下肢 7 級であり、 歩行は可能だが左足が尖足になりやすく、左手での細 かい作業は困難な状況である。その他、てんかんの疑 いによる痙攣、左側視野狭窄の可能性を有する。言語 によるコミュニケーションは良好である。

生育歴は、在胎 25 週、出生時体重 $618 \mathrm{~g}$ 、帝王切開 により仮死出産した後、蘇生した。呼吸遍迫症候群、 貧血、黄疸、動脈管開存症、慢性肺疾患が認められ、 5 か月間人工呼吸器による管理が行われた。頸定 10 か 月、おすわりとはいはいは 1 歳 2 か月、つかまり立ち 1 歳 7 か月、伝い歩き 1 歳 9 か月、一人歩き 2 歳 4 か 月、片言で話したのは 1 歳時であった。気管支喘息、 熱性痤攣（てんかんの疑い）の既往があり喘息予防薬 服用、年 1 回の脳波検査では異常はみられないが、3 年間抗媛攣剂を服用し、小学校入学時に漸減中止し た。I病院の小児リハビリ室に 1 歳時より通いはじめ、 週 1 回作業療法士によるリハビリを受けているほか、 スイミング、ピアノ、新体操の教室に通っている。 3 歳時に、それまで通っていた障害幼児通園施設から地 域の保育園に入園、通園した後、現籍校に就学した。

\section{2. 学習面、行動面、情緒面の様子}

担任により記載された、入学後 1 か月ほどしての学 校での様子は、次のとおりである。

聞く：集中して聞いたことはよく理解できるが、集 団における一斉指示は聞き漏らすことが多い。話す： 日常会話はスムーズで、年齢相応の表現力がある。自 分が思っていることを周囲に伝えることができる。読 む：平仮名はすべて読むことができ、片仮名も半分ほ ぞ読める。年齿相応の内容の本も、つかえずに読むこ 
とができる。書く：利き手である右手に筆記用具を もつて書くことができる。平仮名等の書字は、手本と の違いは意識できるが、字形を整えて書くことができ ない。なぞり書きを正確にすることができない。筆圧 が弱い。4 月に顔の描写をしたときは目鼻の位置が右 に偏っていたが、5月になって家庭で一人で描いた母 の日の絵では真ん中になっていた。計算する：数詞と 対応させながら、50くらいまで数えることができる。 推論する：10 までの 2 数の直接対応による比較では、 「同じ」「多い」「少ない」と答えることができる。直 感的にとらえられる数は 4 5 までである。

行動面：集会などの整列の際、意識させないと列か ら右にずれて並んでしまう。書字や作業のときに左手 を使わないことが多かったが、書字の際、自然に左手 を机上に置くなど、使うことが增えてきた。遠足の翌 日に作文を書いていたときに、疲れていたためか、直 前まで形のとれていた平仮名も、突然形がとれなく なった。本人は、きちんと書いたつもりで読んでいた。 急に筆圧が弱くなることもある。気が散って集中力も 低下し、「頭が疲れた」「頭が㗢かない」などといって、 数分しか課題が行えないことがある。算数などで、答 えはわかるが、答えを選択して線で結ぶような課題に なると、適当に答えを結んだり、すべてを線で結んだ りと、どうしたらいいのかわからなくなってしまう。

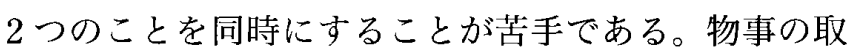
りかかりが遅く、時間にあわせて急ぐことができな い。次は何をするべきかを考えて行動することが苦手 である。

情緒面：失敗体験や障害による困難さからくる情緒 的不安定な様子は、いまのところみられない。

\section{3. 小学校入学までの書字、描画の様子}

母親からの聞き取りによる、対象児の小学校入学以 前の書字の様子は次のとおりである。

1 歳 6 か月健診時、鉛筆で自由に書く課題では、ほ んとうにかすかな、かすれた弱い線だった。「鉛筆で 書く」という指示は理解してやっていたが、そのとき がはじめてだった。よく子どものする、グルグルと円 状の線を書く殴り書きをクレヨンでやりはじめたの は、2 歳半ごろで、スタートが遅かった。お絵かきや 塗り絵遊びの経験がほとんどないまま（通園していた 障害幼児通園施設では、お絵かきなどの活動はしな い)、地域にある保育園入園になった。入園当初は書 くことに関して本人に、「できない」という思いが積 み重なった。書字以前の筆圧の問題、線をなぞる段階 （指先のコントロール）がまだ確実にできていない。
（ジグザグやグルグルのなぞり書きなど）迷路も苦手 だった。

文字を書きたい（文字にならなくてもそれらしく書 いて、あるいは絵を描いて表現したい）思いはとても 強く、自己流であってもイメージはもっていて、書く （描く）という行為には特別な気持ちがあった。しか し、文字の練習を親が強制することはしてこなかっ た。2歳ころから 6 歳のいままで、自分から思い立っ ては、紙とペン (鉛筆) を持ち出して書いている。

お手本を見て書くことが苦手なようで、自由に見立 てて（悪くいえば自分勝手に）書くことが好き。イ メージとしては、さらさら、すらすら書く。文字（か

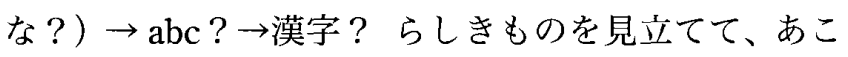
がれの気持ちから真剣に、根気よく紙面いっぱいに、 うねつた短い線をたくさん書き込んでいた。知らない 文字を教えると喜ぶが、見本と同じようにまねて書こ うとすると、うまく書くことができず、気持ちもつま ずいてしまい、やめてしまうことが多かった。

平仮名も、幼児学習帳にあるなぞる部分に興味を示 さず、なぞって、まねて覚えて、次に書けるようにな るというステップが続かなかった。ことばの理解力が ある分、親は不思議でたまらなかった。

4 歳 7 からごろに、逆さ文字や鏡文字はなくなった。 名前が書けたのも、このころ（年中の春）だった。 「ひ」が書けるまで、ずいぶん時間がかかった。「ひ」 は「ぶらんこ」と教えてもらってから、書けるように なった。年中終了時、名字の「わ」が書けず、他児 は全員氏名を書いていたが、本人は名前だけ書いて いた。

マス目に、同じ大きさで大きく書くことができな かった。補助の十字線の中のマスに4つ書いてしま い、外枠に合わせて大きく一文字書くことができな かった。そんな理由で、学習帳が嫌いになった。

横書きで書くときは、左下から右上に向かって斜め に書いていた。「ありがとう」では、「あ」がいちばん 下で斜めに「う」に向かって上がっていく。紙全体の 中でバランスを取って書くことは、幼いからではな く、独特に苦手なような気がしていた。園の行事で縦 長の短冊に願い事を書くときに、縦書きで書きはじめ た字が右に寄ってしまい、紙の端まで来てもそのまま 修正できず、続きが書けなかった。便せんやカードに 手紙を書くときも、続きを書く場所がわからなくなっ たりして苦労していた。

書き順は自己流だが、平仮名は自分で少しずつ練 習して書けるようになった。いま（小1の5月）は、 


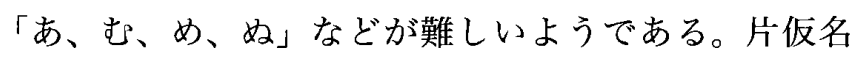
は、ほとんど書く練習をしていない。

\section{III. 経過と結果}

\section{1.アセスメントの方法}

対象児が在籍する学校を筆者が訪問し、担任、保護 者からの対象児に関する情報収集、および対象児に WISC-III、K-ABC 心理・教育アセスメントバッテリー (以下 K-ABC とする)、DTVPを実施する。以上の結果 から、対象児がもつ書字、描画困難の原因についてア セスメントを行う。なお筆者は、特別支援学校の地域 支援部で、専任の特別支援教育コーディネーターとし て、地域の小中学校等に在籍する肢体不自由児や LD 等の発達障害をもつ子どもの教育相談を主として行っ ており、学校心理士および特別支援教育士の資格を もつ。

\section{2. 情報収集および各心理検查の結果}

（1）対象児に関する情報収集：対象児が 6 歳 8 か月時の 4 月 27 日に 1 回目の訪問を行い、担任および
保護者より、対象児に関する聞き取りと資料の提供を 受けた。それらをまとめたものは、「II．対象児」に記 述した。

（2）WISC-IIIの結果：対象児が 6 歳 8 か月時の 5 月 1 日に 2 回目の訪問を行い、WISC-III を実施した。 結果は Fig. 1 のとおりである。言語性 IQ は 108、動作 性 IQ は 58 、全検査 IQ は 82 で、言語性 IQ と動作性 IQ の間には $5 \%$ 水準で統計的に有意な差がみられた。 群指数は言語理解が 112、知覚統合が 58 、注意記憶が 94、処理速度が 78 で、注意記憶と処理速度以外の群 指数間に $5 \%$ 水準で有意差がみられた。群指数のパ ターンは (2)（海津, 2005）であった。下位検査では、 積木模様（評価点 3) と組合せ（評価点 2) が特に低 かった。検査中の様子はリラックスしており、背伸び やあくびをすることもあった。手いたずらや無駄口が 多く、離席することも多々みられ、途中で飽きたり、 疲れてきたりする様子もみられたが、休䄸や気分転換 をしてやると再び検査に集中できた。検査に要した時 間は、休㦝も含め約 100 分間であった。左手に麻痺が
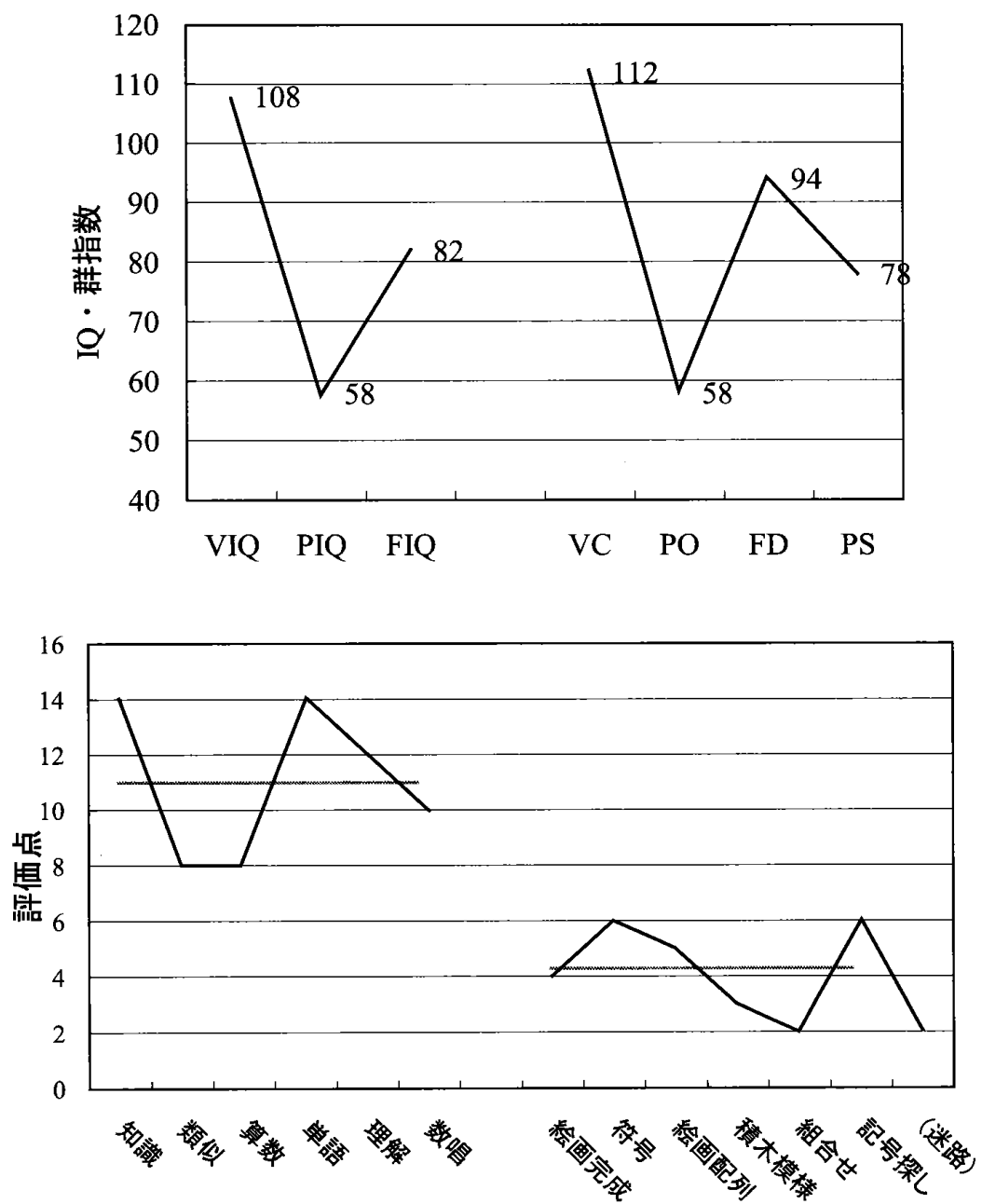

Fig. 1 WISC- IIIの結果 
あるが、右手をおもに使い左手も補助的に使うこと で、検査用具の操作に大きな影響はみられなかった。 言語性検査では、答えに関することや無関係なことを よくペラペラとしやべっていた。算数では、指を使っ て計算していた。積木模様では、自分の間違いに気づ いていない様子であったが、組合せでは「ひとつもで きたのがないよね」と自分で言っていた。記号探しで は、「あるから‥、ないから‥」と一つ一つ慎重にやっ ていた。

(3) K-ABC の結果：対象児が 6 歳 8 か月時の 5 月 8 日に 3 回目の訪問を行い、K-ABC を実施した。結 果は、Fig. 2 のとおりである。継次処理 107、同時処理 78 で、継次処理が $1 \%$ 水準で有意に高かった。認知処 理過程は 89、習得度は 92 で、再者に有意差はみられ なかった。継次処理に関する課題では集中して取り組 んでいたが、同時処理に関する課題は、〈絵の統合〉 を除き、途中から集中力がなくなって休憩を要求した り、離席するなど落ち着かない様子がみられた。〈視 覚類推〉の 13 番を終えたところで「休み時間にして ください」と言ったので、5分間の休憩をとつた。習 得度に関する課題でも〈算数〉は比較的集中してやっ ていたが、それ以外の課題では、途中で立ち上がった り、床に德転んだりしながら答えたり読んだりする様 子がみられた。最後の〈文の理解〉では、はじめ落ち 着かない様子で立ち歩いて「やーだよ」といつてなか なかやりはじめてくれなかった。検査に要した時間

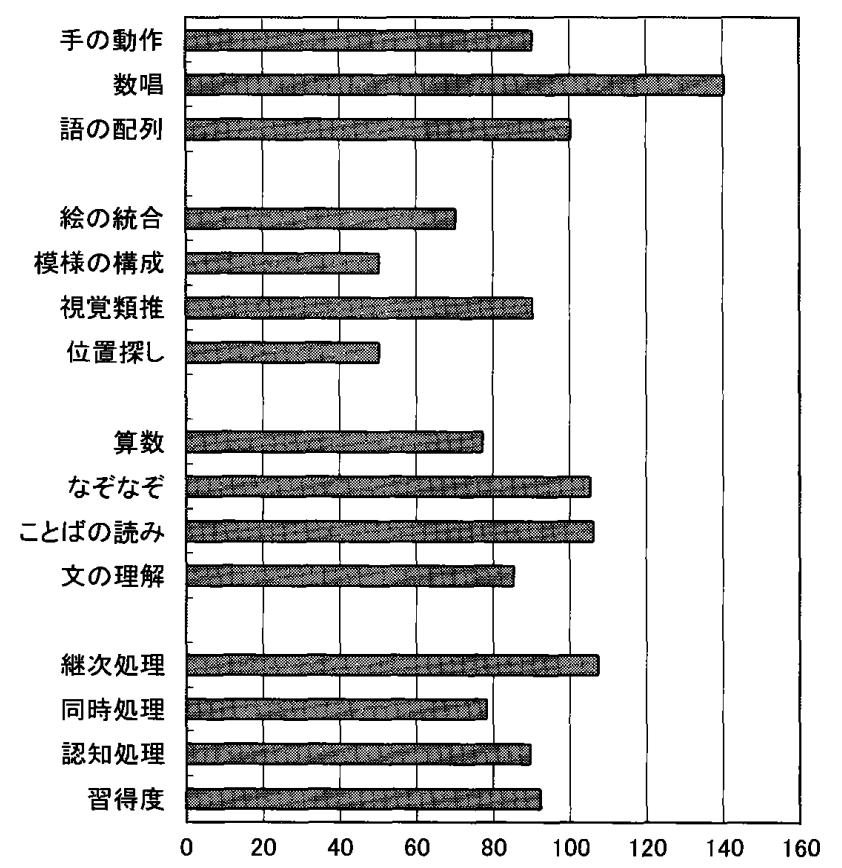

Fig. 2 K-ABC心理・教育アセスメントバッテリー の結果
は、休憩も含め約 75 分間であった。

(4) DTVP の結果： K-ABC 実施後 20 分間の休 憩をとってから DTVPを実施した。結果は、Fig. 3 の とおりである。知覚指数は換算範囲を下回ったため、 換算できなかった。全体的には楽しそうに取り組んで いたが、苦手な課題には拒否を示すこともあった。ま た、検査用紙の余白に数字の羅列を書くなど、落ち着 かない様子もみられた。検査に要した時間は約 35 分 間であった。

(1) 視覚と運動の協応：知覚年齢（以下PA とする） 4 歳 3 か月、評価点（以下 SS とする）は 6 であっ た。始点と終点を意識して線が引けている。麻痺 があって鉛筆の操作が苦手であることを考慮して も、十分にコントロールした線が引けている。水 平方向、垂直方向に引くことは上手であるが、斜 めや曲線では、線が曲がってしまう。

(2) 図形と素地：PA 4 歳 3 か月、SS は 7 であった。 線の交差や地と図を区別して形を縁どることがで きているが、ときどき、線が交差するところで別 の線を縁どってしまうこともあった。

(3) 形の恒常性：見てすぐに「難しい、やりたくな い」と拒否をしたため、実施しなかった。

(4)空間における位置：PA 5 歳 1 か月、SSは8 8 で あった。最後の 3 問を間違った。WISC-IIIや K-ABC でみられたように、幾何学模様への弱さや左右逆 に認知するといった間違いの特徵がみられた。

(5) 空間関係：PA 5 歳 9 か月、SS は 9 であった。最 後の 2 問は、課題を見たとたん「やりたくない」 と拒否をしたので、実施しなかった。

\section{3. 対象児の情報および心理検査結果からの考察}

WISC-IIIの結果では、全検査 IQ は境界線〜平均の下 であるが、言語性 IQ と動作性 IQ に有意な差があるた め解釈には慎重を要し、特に、動作性検相に含まれる 各能力に困難をもっていることが推測された。K-ABC の結果では、継次処理が同時処理や習得度に比較して 強かった。海津（2005）によると、WISC-III の言語性 $\mathrm{IQ}$ と $\mathrm{K}-\mathrm{ABC} \sigma$ 継次処理能力には関連があり、両者と も強い得意な能力として示され、同様にWISC-IIIの動 作性 IQ と $\mathrm{K}-\mathrm{ABC}$ の同時処理能力の両者とも弱く、不 得意な能力として示されたという結果から、両方の検 査結果に対する信頼性は高いと考えられる。

対象児の能力では、まず、WISC-IIIの言語性 IQが高 いこと、群指数では言語理解が他の 3 つに比べて非常 に高いことや、K-ABCの「なぞなぞ」や「ことばの読 み」の評価点が高いことから、本児は基本的には言語 
による理解や指導が有効であることが考えられる。

一方、WISC-IIIの知覚統合の低さや K-ABCの「模様 の構成」と「位置探し」の評価点の低さから、対象児 は抽象的刺激を目でとらえにくい、部分と全体との関 係が視覚的にとらえにくい、視覚を使った図形等の再 構成が苦手、視覚でとらえたものを分析する力の弱 さ、というようなことが推測される。視覚に関しては、 DTVPからも WISC-III と K-ABCの下位検査でみられた のと同様の左右の逆転による䛊りや、図形を失認して しまう誤りが認められた。しかし、WISC-IIIの「符号」 や「記号探し」の評価点の高さから、同じ視覚を使っ た課題でも、対象の認識や形状の比較といったことは 可能である。このことは、「読む」ことはできるが「書 く」ことに困難がある、書いたものが手本と違うこと はわかるが手本と同じように書けないといった現在の 状態と一致しており、脳性麻痺児の視覚一運動障害の 基本的な問題は、対象の認知・弁別（視知覚）の障害 ではなく、認知・弁別したものの構成（再生・表現） の障害であるとした显地（1984）の知見と同様である。
以上の検査結果と行動観察から推測された特性は、 対象児がもつ脳の器質障害 (PVL) に起因寸る機能障 害の一般的特性と一致し、空間認知に関する視知覚障 害および随意的眼球運動などの視覚運動機能障害を有 していることが推測される。一方、符号を書く、線で 結ぶ等の運動は可能であり、手の麻痺が書字困難の主 たる原因である可能性は低いと考えられる。

対象児は、目の左側に視野狭窄があるため、視覚入 力系に基本的な困難さがある。また、PVLにより、視 覚や運動に関する情報の受け渡しを行う部分の障害も もっていると考元られる。さらに、肢体不自由に起因 する、自力での移動経験の少なさからくる空間把握の 困難も推測される。これらの要因が複雑にからまっ て、結果的に視知覚や視覚的認知、視覚と運動の協応 に困難を生じていると推測される。そこで、対象児の 書字、描画困難の改善のためには、視知覚の困難に対 する指導・支援が必要であると考えられた。

\section{4. 指導・支援方法}

アセスメントにより推測された視知覚の困難からく

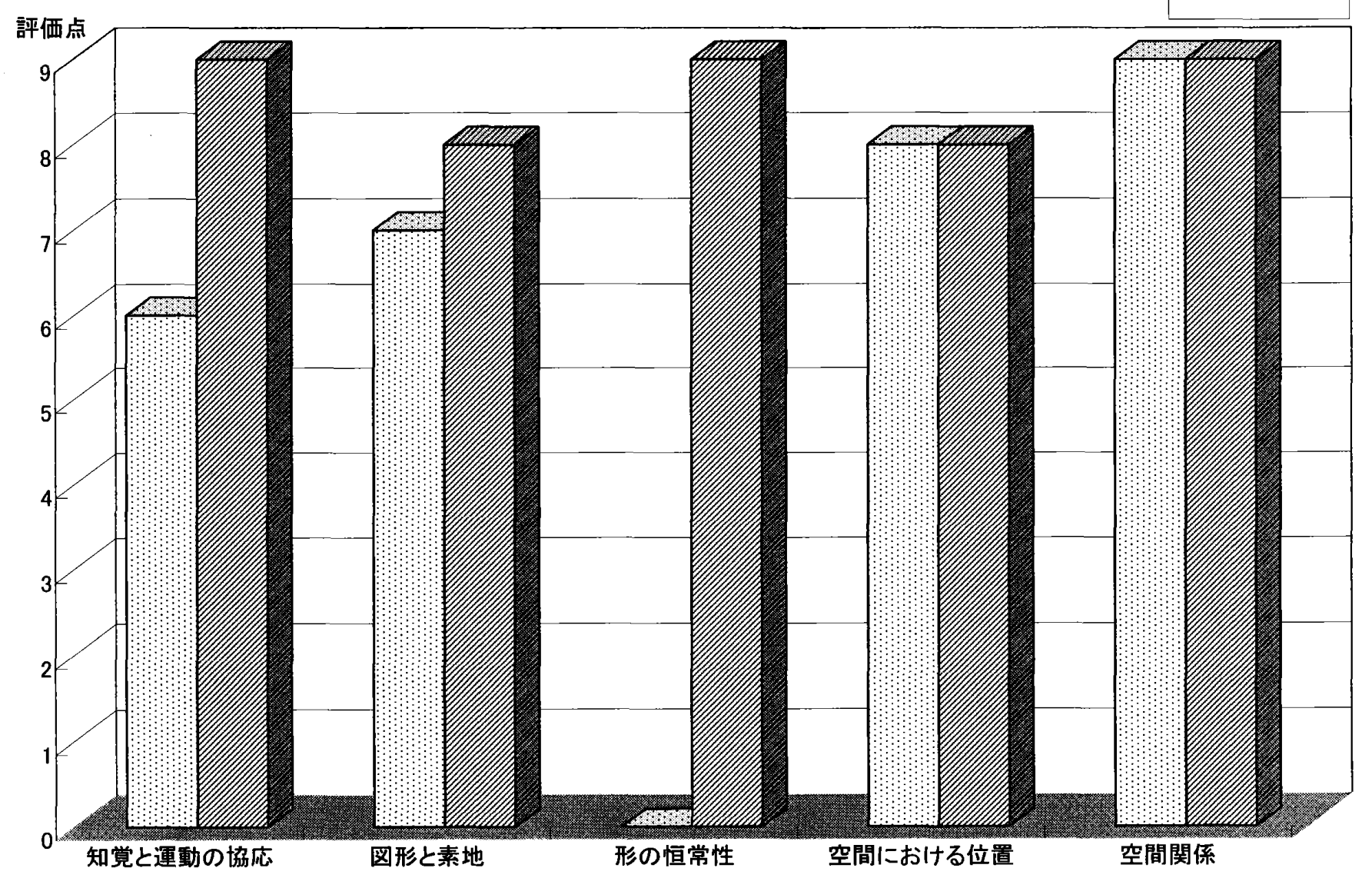

Fig. 3 フロスティッグ視知覚発達検査の結果 
る認知特性を担任教師および保護者に説明し、視知覚 の改善および眼球運動を主とする視覚機能の向上のた めに、学校で担任によってできる指導として以下の項 目を行った。担任教師は大学で障害児教育を専攻し、 卒業後は産休代替などの臨時的任用や、 1 年間の期限 付き採用などで 10 年以上の小学校教員としての経験 をもつが、特別支援学級の担任をするのははじめてで ある。なお、担任は対象児が 2 学年になったときも持 ち上がり、指導については継続して行った。

指導経過の評価と必要に応じて指導方法の修正を行 うために、地域支援による訪問相談を行い、対象児の 観察と書字、描画に関する様子について担任や保護者 から情報提供を受け話し合いを行う。訪問は、担任ま たは保護者の必要に応じ実施することにした。

対象児の指導経過と合わせて指導の効果を客観的に 評価するために、1年後にDTVPを実施し検討する。

（1）フロスティッグ視知覚能力促進法を参考に した指導： Frostig, Horne, and Miller (1972a, 1972b) を参考に担任が作成したプリント課題を 1 日 1 枚、授 業の合間に行う。課題の量と内容は、学習ブックの初 級編から順に、本児の修得度を担任が判断しながら進 めていく。また、1日のうちのどの時間に実施するか は、その日の時間割と授業内容により担任が判断す る。なお、筆記用具は、持ち方の補助となるゴムグ リップを装着した 4Bの鉛筆を使用する。

（2）ビジョントレーニングを参考にした指導： 内藤（2002）によるビジョントレーニングを参考に、 (1) 4 つの隅、(2) 眼体操、(3)ヘッドスイング、(4) 数字 サッカード、(5)眼のフル回転、(6)ドアジャンプの各 課題を、担任が毎日指導する。おもに休み時間に課題 を分けて行い、1 日あたり合計約 15 分間行う。

（3）学習全般にわたる指導・支援：以上の指導 のほか、視覚を使う学習に関する指導・支援について、 担任および保護者と以下の事項を確認した。

(1) 学習においては、得意な言語刺激を用いて理解を はかるようにする。視覚的抽象刺激はことばで意 味づけしながら覚えるようにする。

(2) 文字や図は見本を見て書くだけではなく、空書、 なぞり書きをしながら、手の運動として覚えるよ うにする。その際、はじめは教師が本児の手を 取って一緒に書いたり、線の方向などをことばで 言いながら書かせたりするなど、身体的援助やこ とばによる補助もあわせて行うようにする。

(3) 眼球運動を向上させるための指導として設定さ れた時間以外にも、普段の学習の中に、楽しみ
ながら目を意識して動かす課題を設定し学習を 行う。

(4)目を使う課題を多く行ったときや身体的運動に よって疲労がたまったときには、目や体を休め る、気分転換をするといった配慮をする。

\section{5. 結 果}

（1）書字および描画の指導経過および担任、保 護者とのコンサルテーション

5 月 23 日：心理検相等から推定された対象児の書字 や描画の困難について、担任と保護者に説明した。そ して、学校でできる改善のための指導について話し合 い、前述した指導を行うことで合意がはかられた。

9 月 14 日：平仮名と片仮名については、すべての 文字を書けるようになっていた。しかし、視写すると きに見本と同じように一つ一つのマス内にはみださな いで書くことはできるものの、マス内でバランスよく 書くことはできず、大きさや配置がばらばらであつ た。人物画については、顔は目、鼻、口の位置関係は 正しく描かれているものの、胴体と手足は形や配置が イメージできていないようで、線は単純で、交差した り途切れたりしているところもあった。

12 月 15 日：書字に関しては、これまでに習った漢 字をすべて覚えて書くことができていた。しかし、意 識してていねいに書くときは、うまく書けるときもあ るが、止め、はね、はらいや線の長さ、字形など、雑 なときが多かった。人物画は、大きく描くことに慣れ てきて、顔や胴体や手足が明確になってきた。ここま での指導経過から、担任との話し合いにより、順調に 指導の効果が現れているという評価になり、3学期も 引き続き現在の指導を継続することが確認された。

次年度（対象児が 2 学年）の 5 月 25 日：書字に関 しては、鉛筆にゴムグリップは装着しているが、筆圧 が上がり、2B の鉛筆で濃い線が書けるようになった。 止め、はね、はらいなどは意識できていないが、漢字 もマス内に適切な大きさで字形を整えて書けるように なった。消しゴムの使用に関しても、必要なところの みが消せるようになつた。人物画については、顔や全 身の各パーツの把握やバランスなど、同年齢の子ども とほぼ同じ水準で描けるようになった。

7 月 11 日：5月の訪問時に実施したDTVPの結果 について、同日に担任と保護者に説明を行った。対象 児の書字、描画の様子と DTVPの結果について話し合 い、これまでの指導が有効であるという評洒がなさ れ、引き続き同じ指導を継続することが確認された。

年明け 3 月 5 日：対象児は、 2 年生の新出漢字 160 
字をすべて覚えて書けるようになっていた。交流を 行っている通常学級担任から「字がうまくなった」と ほめら続け、周囲の友達にも「字がきれい」「字がう まい」と声をかけられ、本人はますます自信をもって 書くことを楽しんでいるということであった。ここで の担任、保護者との話し合いにより、対象児の書字や 描画の困難はほぼ改善されたということになり、改善 のために行っていた指導を終了することにした。

（2）1 年後の DTVP の結果：対象児が 7 歳 8 か 月時の 5 月 25 日の訪問時に筆者が実施した。結果は、 Fig. 3 のと抢りである。知覚指数は 78 であった。検査 全体を通じて、楽しそうに集中して取り組めた。検査 に要した時間は 45 分であった。

(1) 視覚と運動の協応：PA 7 歳 0 か月、SS は 9 で あった。始点と終点を意識して線が引けている。 斜めや曲線でも、方向を意識してコントロールし た線が引けている。

(2) 図形と素地：PA 5 歳 8 か、SS は 8 であった。 線の交差や、地と図を区別して形を縁どることが できている。

(3) 形の恒常性：PA 6 歳 7 か月、SS は 9 であった。 「ここにもある、ここにもある」と、宝探しをす るように楽しんでやっていた。

(4)空間における位置：PA 5 歳 8 か月、SSは 8 で あった。 1 年前の検查時と同様に、 6 番目と 8 番目 を間違えたが、7 番目はできていた。

(5) 空間関係：PA 6 歳 6 か月、SS は 9 であった。 7 番目は最後の 1 本の位置を間違えただけであっ た。8 番目の課題も、ほとんどの線が引けていた。

\section{IV. 考 察}

\section{1. 対象児の書字および描画困難と指導の効果につ} いて

対象児に実施した WISC-IIIの群指数のプロフィール では、言語理解と注意記憶が高く、知覚統合と処理速 度が低いという、脳性麻㯅児に現れやすい逆 $\mathrm{N}$ 字のパ ターン（川間, 2008）を示した。また、動作性下位検 査の評価点では、「積木模様」「組合せ」が評価点 3 以 下で本児の中では弱い能力として示された一方、「符 号」と「記号探し」は評価点 6 で本児の中では強い能 力として示された。K-ABC の認知処理過程では、同時 処理が有意に低く、「模様の構成」と「位置探し」の 評価点が 5 と、他に比べて低い結果であった。DTVP では、「視覚と運動の協応」「図形の素地」が評価点 7 以下であり、「形の恒常性」は、課題を見たとたんに
やりたくないといって実施できない状況であった。

この WISC-III とDTVP の結果は、低出生体重児を対 象に PVL と視知覚認知に関して対象児を横断的に比 較検討した荏原ら（2005）の結果、および対象児の指 導経過について縦断的にDTVPの結果から検討した山 口（2008）の結果と同様であり、対象児は、脳の背側 皮質視覚路の損傷による空間認知に関する視知覚障 害、および随意的眼球運動などの視覚運動機能障害を 有していることが推測された。一方、同じ視覚を使っ た課題でも、WISC-IIIの「符号」や「記号探し」の評 価点の高さに代表されるように、対象の認識や形状の 比較といった腹側皮質視覚路で処理することは可能で あり、その部分の損傷は少ないと考えられた。また、 符号を書く、線で結ぶなどの、「鉛筆を使って書く」 といった運動自体も可能であり、手の麻痺が書字困難 の主たる原因である可能性は低いと考えられた。

そこで、対象児の書字、描画困難を改善するために、 フロスティッグ視知覚能力促進法を参考にした指導と ビジョントレーニングを参考にした指導を、担任教師 により学校で継続的に行ってきた。その結果、書字に ついてはマス内にバランスよく書けるようになった り、新出漢字を覚えたり、周囲から字が上手になった とほめられたりと、書字能力の向上がみられ、書くこ とに対して、自信をもって楽しんで取り組めるように なった。人物画についても、顔や全身の各パーツの把 握やバランスについて、同年齢の子どもと同じ水準で 描けるようになった。また、 1 年後に実施した DTVP の結果では、「知覚と運動の協応」「図形と素地」「形 の恒常性」の評価点が向上し、「空間関係」では評価 点に変化はなく、この結果は荏原ら（2005）や山口 （2008）の結果と同様になった。しかし、対象児の場 合「空間関係」の評価点に変化はみられなかったが、 初回の DTVPのときは 7 番目と 8 番目の課題は見たと たんに「やりたくない」と拒否を示した。2 回目では、 得点にならなかったものの、ほとんどの線を正しく引 くことができ、空間のとらえに質的な向上がみられ た。そして、対象児の書字、描画困難の改善期間につ いては、伊藤・冨田（2004）や山口（2008）と同様に 1 年以内に顕著な効果が現れている。

以上のことから、対象児の書字、描画困難の主たる 原因は、PVLによる脳の背側皮質視覚路の損傷による 空間認識に関する視知覚障害掞よび皮質脊䯑道路の損傷 による視覚運動機能障害であると考えられ、その改善 のための指導として担任教師により学校で継続的に 行ってきた、フロスティッグ視知覚能力促進法を参考 
にした指導については一定の効果があつたと考えられ る。しかし、あわせて行ったビジョントレーニングを 参考にした指導については、本研究では指導前後の比 較データの収集ができなかったため、効果測定のため のデータの収集方法などの検討が必要である。

\section{2. 肢体不自由児への地域支援のあり方について}

安藤ら（2006）は、通常学級に在籍する脳性麻痺児 の認知特性に対する教師の気づきに個人差があり、脳 性麻痺児の認知特性の理解と指導に関する専門的情報 の不足を指摘している。肢体不自由児を対象とした特 別支援学級に在籍する児童生徒についても同様の状況 が考えられ、本事例についても、対象児がもつ書字、 描画困難について、担任がどのように理解し、どのよ うに指導したらいいのかわからずに苦慮していた。

特別支援教育体制整備が全国的に進められている中 で、平成 19 年 4 月に改正された学校教育法や平成 21 年 3 月に告示された特別支援学校学習指導要領に、特 別支援学校は地域の特別支援教育のセンター的役割を 果たすよう努めることが規定され、特別支援学校がつ ちかってきた障害児教育に関するノウハウをもとにし た地域の特別な教育的ニーズを有する子どもたちへの 支援がますます期待されている。地域の肢体不自由児 に対しても肢体不自由教育のノウハウをもとに支援し ていかなければならないが、安藤ら（2007）が指摘す るように、麻痺等による身体の不自由さに着目した支 援が主として行われている一方、脳性麻痺などの脳性 疾患を有する児が多くもつ認知特性と学習の困難に 対する気づきと理解を促進する支援は少ない現状に ある。

このような脳性麻痺などの脳性疾患を有する児がも つ認知特性を保護者や教師に理解してもらうために は、地域支援における教育相談等においてエビデンス にもとづく介入が必要である。本研究でも、対象児に 複数の心理検査を実施し、そのテストバッテリーの結 果からアセスメントを行い保護者や担任教師に説明を 行ったことで、スムーズな理解と指導内容・方法につ いて共通理解がはかられ、成果に結びついていった。 このように、本事例や他の先行研究の対象児のように 上肢の操作的な機能に大きな障害がない場合は、心理 検査等を実施して、その結果から子どもの状態を客観 的に分析し、保護者や直接指導にあたる教師に理解し てもらうことが、効果的な指導を行ううえで重要であ ると考える。

また、本事例では、初年度のインテーク時に情報収 集および心理検査の実施、アセスメント結果の説明と
指導方針の確認に 4 日を費やした後、 9 月と 12 月にそ れぞれ 1 回の指導経過の確認と評価のための訪問教育 相談を行ったのみで、順調な経過をたどった。1 年後 にDTVPのみ実施し、その結果と、その時点の書字や 描画の様子から主訴についての改善がはかられてきて おり、同じ指導内容で継続していくという評価になっ た。このように、地域支援において、子どもの状態像 の初期評価をていねいに行うことで、その後の指導が 順調に進み、支援回数を減らすことができると考えら れる。このことは、特別支援学校の業務として行う地 域支援を、より効率的に行うために必要な方法である といえる。

\section{3. 本研究の限界と課題}

本研究では、対象児が有する書字、描画困難に対し て、心理検查等によるアセスメントから認知特性を明 らかにし、改善のための指導としてフロスティッグ視 知覚能力促進法を参考にした指導については、一定の 効果があったと考えられる。しかし、学校における教 育活動の中では、この指導以外にも、担任教師と確認 したようにさまざまな指導や支援が同時に行われてき ており、それらの影響も看過できない。このことは、 今回ビジョントレーニングを参考にした指導について の効果の測定ができなかったこととあわせ、今後の検 討課題である。また、本研究の対象は単一事例である ため、結果と考察においては本事例の範囲でしか言及 できない。そこで、今後、脳性麻痺以外の障害も含め た肢体不自由児の学習上の困難に対するアセスメント や、それにもとづく指導の効果をもとにした肢体不自 由児に対する地域支援のあり方については、事例を積 み重ねながら検討していく必要がある。

\section{文 献}

安藤隆男・野戸谷睦・任 龍在・小山信博・丹野傑 史・原優里乃・松本美穗子・森 まゆ・渡邊憲幸 （2006）通常学級における脳性まひ児の学習の特性 に関する教師の理解. 心身障害学研究, 30, 139-151. 安藤隆男 ・ 渡邊憲幸・松本美穂子 - 任 龍在 - 小山信

博・丹野傑史 (2007) 肢体不自由養護学校における 地域支援の現状と課題. 障害科学研究, 31, 65-73.

荏原実下代・太田令子・伊藤孝子・北原 佶 (2005) 低出生体重児における視知覚の発達特性一Frostig 視 知覚発達検查と Wechsler 系知能検査の結果から一。 リハビリテーション医学, 42, 447-456.

萑原実千代・太田令子・染屋政幸・田辺雄三 (1999) 早産低出生体重児における MRI 所見と視知覚発達 
障害一脳質周囲白質軟化症の臨床的意義一.リハビ リテーション医学, 36, 340-345.

Frostig, M., Horne, D., \& Miller, A. (1972a) Pictures and patterns (rev. ed.). Follett Publishing, Chicago, Illinois. 日本心理適性研究所訳 (1997) フロスティッグ視知 覚学習ブック (初級用). 日本文化科学社.

Frostig, M., Horne, D., \& Miller, A. (1972b) Teacher's guide pictures and patterns (rev. ed.). Follett Publishing, Chicago, Illinois. 日本心理適性研究所訳 (1997) フロスティッグ視知覚能力促進法 (初級用). 日本文 化科学社.

茨聡・荻田幸雄（2000）1.レクチャーシリー ズークリニカル update一, 3）脳室周囲白質軟化症 (PVL)。 日本産科婦人科学会雑誌, 52(9), N-175$\mathrm{N}-178$.

石井 仁・飯塚慎司・築田明教・川端秀仁 - 長嶋祐二 （2007）軽度発達障害児における形態模写過程の基 礎的解析 (ヒューマンコミュニケーショングルー プ (HCG) シンポジウム). 電子情報通信学会技術研 究報告, 106(612), 37-42.

伊藤信寿・冨田 豊 (2004) 構成能力に注目した短期 間の訓練で模写が著しく改善した症直型両麻痺児の 一例. 人間と科学, 4(1), 21-28.

海津亜希子 (2005) WISC- III の解釈と指導・支援への 展開.上野一彦・海津要希子・服部美佳子 (編), 軽度 発達障害の心理アセスメントーWISC-IIIの上手な利 用と事例一, 日本文化科学社, 35-65.

川間健之介（2008）第 1 部第 4 章 肢体不自由という障 害の理解 2 心理学的な理解. 筑波大学附属桐が丘 特別支援学校 (編著)，肢体不自由教育の理念と実 践. ジアース教育新社, 81-90.

木村美樹 - 渡辺直美 - 西 範子 - 小枝達也 (1992) 脳 性麻㽻病直型両麻痺児の視知覚の特徵 第 2 報 訓 練効果からの検討. 作業療法ジャーナル, 26, 366370 .

小枝達也 (1993) 脳性麻痺と視覚認知障害. 有馬正高 · 加我牧子 (編), 発達障害医学の進歩 5. 診断と治療 社, 98-103.

小枝達也 - 渡辺直美 - 木村美樹 - 西 範子 - 竹下研三
（1990）けい性両麻ひ児の視覚認知障害とその病巣 について. 脳神経, 42, 759-763.

松本政悦・北村由紀子 (2000) 視知覚に問題がある子 ぞもの習字練習の経験。リハビリテーション研究紀 要, $10,19-21$.

内藤貴雄 (2002) 勉強嫌い, 集中力のなさは「眼」が原 因だった，二見書房．

仲山佳秀（1984）㽷直型脳性麻㾝児における構成障 害一認知的側面からの検討一. 教育心理学研究, 32, $247-255$.

奥村智人 - 若宮英司 - 宇野正章 - 藤庭真也 - 阪上由 子・竹内義博・玉井 浩 (2008) コンピューターソ フトを用いた眼球運動トレーニングの効果一頭頂 葉・後頭葉萎縮を認める症例の視写困難に関する検 討一. 小児の精神と神経, 48, 135-142.

酒井薰美・山田孝 (2001) 痤直型両麻痺児, 痙直型四 肢麻痺児の視知覚系の改善に及ぼす感覚統合療法の 効果. 作業療法, 20, 106-115.

曻地勝人 (1971) 脳性マヒ児の視覚-運動機能の分析 的研究一認知 と構成一. 心理学研究, 42, 56-66.

曻地勝人（1978）脳性マヒ児の視覚一運動機能の発達 的研究. 心理学研究, 49, 249-256.

旦地勝人（1983）脳性マヒ児の回転的図形構成に関す る研究. 心理学研究, 54, 222-228.

开地勝人 (1984) 脳性マヒ児の視覚・運動機能の特性 一認知機能と構成機能一. 障害児のパターン認識に 関する総合的研究. 特別研究報告書, 国立特殊教育 総合研究所, 107-116.

高橋尚人 (2002) これからの新生児医療. 産婦人科治 療, 85, 318-323.

山口 文 (2008) 脳質周囲白質軟化症における「視覚 と運動の協応」のトレーニングに関する一考察. 理 学療法学, 35 (supplement 2), 604 .

山中克夫 - 藤田和弘 - 名川 勝 (1996) 情報処理様式 を活かした描画と書字指導一継次処理様式が優位な 一脳性麻禆幼児について一. 特殊教育学研究, 33(4), 24-32.

-2009.11.26 受稿, 2010.6.19 受理一 


\title{
Practical Research
}

\section{Improving Itinerant Consultation and Guidance at a Special Support School Through Assessment of Cognitive Characteristics of a Child With Cerebral Palsy}

\author{
Toshiyuki HosAKA \\ Fujimi School for Special Needs Education \\ (Nirasaki-Shi, 407-0046) \\ Present affiliation: Kofu School for Special Needs Education \\ (Kofu-Shi, 400-0064)
}

The present case study focused on an elementary school girl with cerebral palsy caused by periventricular leukomalacia, who had difficulty in writing and drawing. She was 6 years 7 months of age at the first consultation. Her cognitive characteristics were assessed using several psychological tests, including the Frostig Developmental Test of Visual Perception. The results of the tests suggested that her difficulty in visual cognition was more responsible for her problems in writing and drawing than her physical palsy was. These results were explained to her teacher, who was then guided in conducting training suitable for the girl's cognitive characteristics. A year later, the Frostig Test was administered to her again. Her scores for eye-motor coordination, figure-ground, and constancy of shape had improved. In addition, she became to be able to write characters with balanced shapes inside boxes and to draw human figures well enough for her age so that the figures had a good shape and the face and body parts were balanced. Causes of her problems in writing and drawing, effects of the training, and an ideal method of itinerant consultation were discussed.

Key Words: cognitive characteristics, special support school, itinerant consultation, child with cerebral palsy 